\title{
Pharmacological enhancement of naltrexone treatment for opioid dependence: a review
}

\author{
This article was published in the following Dove Press journal: \\ Substance Abuse and Rehabilitation \\ 3I May 20I I \\ Number of times this article has been viewed
}

\section{Paolo Mannelli \\ Kathleen S Peindl \\ Li-Tzy Wu}

Department of Psychiatry and Behavioral Sciences, Duke University Medical Center, Durham, NC, USA
Correspondence: Paolo Mannelli Department of Psychiatry and Behavioral Sciences, Duke University Medical Center, 2218 Elder Street, Durham, NC 27705, USA

Tel + I 9196683757

Fax + I9196685418

Email paolo.mannelli@duke.edu
Purpose: Opioid dependence (OD) is a serious and growing clinical condition with increasing social costs that requires expanding treatment beyond opioid agonist substitution. The opioid antagonist naltrexone has displayed a remarkable association of theoretical effectiveness and poor clinical utility in treating OD due to noncompliant behavior and low acceptability among patients, only partly modified by psychosocial interventions. We reviewed pharmacological studies, including naltrexone depot formulations and combination treatments.

Method: We searched PubMed for clinical studies on the use of naltrexone implants and slow-release injections in OD, and investigations using adjunct medications to improve naltrexone maintenance therapy of OD. We discussed the results in view of their application to the clinical practice.

Results: Significant reduction in opioid use and improved retention in treatment have been found in several studies using depot naltrexone formulations, some of which are controlled clinical trials. Pilot investigations have gathered initial positive results on the use of naltrexone in combination with serotonin reuptake inhibitors, $\alpha$ - 2 adrenergic, opioid, and $\gamma$-aminobutyric acid agonist medications.

Conclusion: Current evidence suggests that more research on effectiveness and safety is needed in support of depot naltrexone treatment for OD. Further research comparing slow-release with oral naltrexone and opioid agonist medications will help characterize the role of opioid antagonist-mediated treatment of OD. Preliminary investigations on naltrexone combination treatments suggest the opportunity to continue study of new mixed receptor activities for the treatment of OD and other drug addictions.

Keywords: extended-release, naltrexone, implant, injection, depot, combination

\section{Introduction}

Illicit opioid use and opioid dependence (OD) are growing critical health issues requiring enhanced prevention and treatment efforts. ${ }^{1,2}$ Only a small proportion of OD individuals currently receive treatment, ${ }^{2}$ and effective options are limited. Agonist maintenance therapy yields better outcomes, but has low availability. ${ }^{3,4}$ There is ambivalence toward this form of treatment in many patients and practitioners. . $^{5-7}$ There is also concern over the clinical correlates of long-term opioid agonist use in several organ systems and in the immune function. ${ }^{8-10}$ Among those who receive opioid agonist treatment, there is substantial attrition and many patients continue to abuse illicit drugs or alcohol, ${ }^{11,12}$ as if craving and appetitive behaviors were not consistently controlled. ${ }^{13}$ The opioid antagonist naltrexone is the only approved medication for OD that is not a controlled substance, nor does it display abuse potential. Thus, it offers a safe alternative for treatment expansion. Unfortunately, using naltrexone to treat OD 
patients has shown limited benefits, compared with the opioid agonist methadone and buprenorphine. ${ }^{14-16}$

The validity of an antagonist therapy of OD was proposed by Wikler, ${ }^{17}$ and is based on the behavioral concept of "extinction." The euphoric effects of opioids reinforce the self-administration behavior and are blocked when an individual is being treated with naltrexone. The continuous lack of reinforcement would gradually result in the extinction of such behavior. However, naltrexone has been successful only among highly motivated groups of OD, including impaired professionals, parolees, and probationers. ${ }^{18-21}$ Others emphasize the importance of close supervision for a successful naltrexone therapy approach, which would explain widely divergent outcomes. ${ }^{22,23}$ Studies have also shown that a comparatively low proportion of patients choose to start naltrexone treatment. ${ }^{24}$ Among those who do, many drop out early: one quarter after a few days, ${ }^{25}$ and as many as half in the first few weeks of treatment. ${ }^{26}$

Along with other reasons for poor treatment retention and low patient compliance, there may be the lack of drug reinforcement when naltrexone is taken and the lack of negative consequences, including withdrawal symptoms, when it is discontinued. It has also been suggested that patients are reluctant to take naltrexone because of fear of symptoms, such as dysphoria or depression, ${ }^{27,28}$ despite the lack of evidence collected by reviews and clinical studies on naltrexone treatment for OD. ${ }^{29-31}$

Behavioral therapy and contingency management have been investigated to alleviate naltrexone's shortcomings. Study results have shown that reinforcement for naltrexone ingestion increases treatment retention and compliance with naltrexone therapy. ${ }^{32,33}$ However, recent investigations have underscored limits in the ability of behavioral therapy to help overcome poor adherence to oral naltrexone and suggest considering the use of formulations that do not include daily, or quasi-daily, administration of the medication. ${ }^{34-36}$

The development of sustained-release or depot formulations of naltrexone has been a long-term goal to improve compliance. Pharmacological combination treatments have also received attention to increase naltrexone acceptability. In this paper, we review available evidence on these methods of enhancing naltrexone therapy of OD, as shown in peerreviewed clinical investigations.

\section{Clinical pharmacology of naltrexone}

Naltrexone was developed in the early 1970s and its competitive opioid antagonism was tested in early studies with heroin and other opioids. ${ }^{37,38}$ Daily dosing of oral N-terminal telopeptide (NTX) results in fluctuating plasma concentrations of the drug. ${ }^{39} \mathrm{~A}$ high first-pass metabolism causes the concentration of naltrexone and the active metabolite 6beta-naltrexol to peak within the first hour after oral dosing, followed by a steady decline each day during treatment. ${ }^{40}$ Although the plasma half-life of naltrexone and 6beta-naltrexol is only 10-12 hours, ${ }^{41}$ studies using $\mathrm{C} 11$ carfentanil have shown that a single $50 \mathrm{mg}$ dose blocks brain $\mu$ receptors for $48-72$ hours, ${ }^{42}$ with plasma levels of $1-2 \mathrm{ng} / \mathrm{mL}$ that antagonize the euphoric effects of relevant intravenous doses of heroin. ${ }^{43}$ This duration of action may be an advantage in that one or two missed doses would not leave the patient unprotected. However, clinical studies have shown that missing even a few doses of naltrexone could have negative consequences, leading to full relapse into opioid use and discontinuation of the treatment, despite intensive clinical interventions. ${ }^{36}$ One explanation may be associated with a different naltrexone affinity at opioid receptors. Naltrexone has the highest affinity for $\mu$ receptors, and shows 10-25 times lower affinity for $\kappa$ and $\delta$ receptors (Table 1). Activity at the three main opioid receptor subtypes indicates its ability to modulate dopaminergic, noradrenergic, and serotonergic transmission, influencing the motivational, stress-regulating, and mood-regulating systems ${ }^{44}$ This broad spectrum effect has also been suggested to help control the intake of other drugs and alcohol ${ }^{45}$ and may be significantly reduced with less than daily administration of the medication. Of course the availability of depot preparations or the adjunct of other medications with 'complementary' action at opioid receptors (eg, buprenorphine, see Table 1) may add consistency to naltrexone's effects.

\section{Sustained-release naltrexone Implants}

Several types of naltrexone implants are available for insertion, usually in the subcutaneous tissue of the lower abdominal wall. More extensive published data exist on a few preparations. An implant containing $1 \mathrm{~g}$ of naltrexone compounded with magnesium stearate (Wedgewood Implant ${ }^{\mathbb{R}}$, Wedgewood Pharmacy, Sewell, NJ) releases naltrexone at

Table I Naltrexone and buprenorphine: opioid receptor activity profiles

\begin{tabular}{lllll}
\hline & \multicolumn{4}{l}{ Receptor binding Kior IC I0 } \\
\cline { 2 - 5 } & $\boldsymbol{\mu}$ & $\boldsymbol{\kappa}$ & $\boldsymbol{\delta}$ & ORL-I \\
\hline Naltrexone & 0.37 & 4.8 & 9.4 & $3,818^{\mathrm{a}}$ \\
Buprenorphine & 0.77 & $\mathrm{I} .1$ & 2.2 & $8.4^{\mathrm{b}}$ \\
\hline
\end{tabular}

Notes: Unless otherwise noted, values are from Schmidt et al. ${ }^{46}$ ${ }^{a}$ McLeod et al; ${ }^{47}$ bnendt et al. ${ }^{48}$ 
levels above $1 \mathrm{ng} / \mathrm{mL}$ during 30-60 days, associated with significant inter-individual variation. ${ }^{49}$ Another type of implant containing $1 \mathrm{~g}$ of naltrexone (Prodetoxon ${ }^{\circledR}$, Fidelity Capital, Moscow, Russia) is approved for the treatment of OD in the Russian Federation. Available data suggest that it reaches naltrexone levels above $20 \mathrm{ng} / \mathrm{mL}$, despite considerable inter-individual variation. ${ }^{50} \mathrm{~A}$ third implant formulation consists of sets of 10,20 , or 30 pellets containing a polylactic-based polymer and naltrexone at doses of 1.1, 2.2, or 3.3 g (O’Neil Implant ${ }^{\circledR}$, Go Medical Industries, Perth, Australia). Naltrexone release is found to be $1-2 \mathrm{ng} / \mathrm{mL}$, for 3 and 5 months, respectively with the 10-pellet and 20-pellet implants, and reaches 7 months with the 30 -pellet ones. ${ }^{51,52}$

\section{Clinical studies}

A significant body of uncontrolled studies suggests a superiority of naltrexone implants over oral naltrexone in maintaining OD individuals opiate-free, up to 12 months after initiating treatment and sometimes in large populations. ${ }^{23,53}$ Nonrandomized trials have tested the feasibility of the treatment, ${ }^{54,55}$ and quality of opioid blockade, ${ }^{56}$ showing short- and long-term positive outcomes. ${ }^{57-61}$

Three randomized clinical trials have compared implants to oral naltrexone, placebo, or treatment as usual. Two of them were randomized controlled trials (RCTs).

Hulse et $a l^{62}$ examined the safety and efficacy of the treatment among heroin-dependent individuals in a 6-month RCT. Seventy patients received $50 \mathrm{mg}$ /day oral naltrexone plus placebo implants $(n=35)$ or a single-dose 2.3 g naltrexone implant plus placebo tablets $(n=35)$. Plasma naltrexone levels were found to be between 1 and $2 \mathrm{ng} / \mathrm{mL}$ for a longer time in the naltrexone implant group. Results showed that more patients receiving oral naltrexone had plasma naltrexone levels below $2 \mathrm{ng} / \mathrm{mL}$ in the first 2 months of treatment ( $P=0.001$ and 0.01 , respectively) and a higher proportion of them had resumed heroin use by the end of the study compared with the naltrexone implant group $(P=0.003)$. Time to relapse was shorter among oral naltrexone patients (115 days vs 158 days). One serious adverse event was associated with surgical implantation, and no major adverse events were recorded. Given the association of consistent plasma naltrexone levels with opioid abstinence, the authors suggested the effectiveness of the treatment to be associated with more effective $\mu$-opioid receptor blockade. Secondary data analyses showed that effective treatment was achieved at naltrexone levels between 1 and $3 \mathrm{ng} / \mathrm{mL}$ and that implant treatment was associated with reduced craving and relapse. ${ }^{63}$
In the study by Kunoe et al, ${ }^{64}$ a group of 56 abstinenceoriented patients who completed inpatient treatment for OD were randomly and openly assigned to receive either a 6-month naltrexone implant or the usual no-naltrexone aftercare, including counseling and vocational services. Patients receiving naltrexone had on average 45 days less heroin use and 60 days less opioid use than controls in the 180-day period (both $P=0.05$ ). Blood tests showed naltrexone levels above $1 \mathrm{ng} / \mathrm{mL}$ for the duration of the study. Two patients died, neither of whom had received an implant.

Krupitsky et al ${ }^{65}$ examined three medication groups ( $n=102$ per group) in a 6-month RCT. Patients received naltrexone implant (1000 mg, implanted every other month), oral naltrexone ( $50 \mathrm{mg} /$ day) or placebo. Available data include the results of an interim analysis on 190 patients. Opiatepositive urines at 6 months were lowest in the naltrexone implant group (63\%) and higher in the oral naltrexone and placebo groups ( $87 \%$ and $86 \%$, respectively). Retention was also significantly higher in the naltrexone implant group compared with the other groups $(P<0.01)$.

\section{Injections}

Injectable naltrexone preparations are administered intramuscularly in the gluteal region. Three different formulations, containing naltrexone-loaded microspheres of polymers of polylactide (Naltrel ${ }^{\circledR}$, DrugAbuse Sciences, Inc, Paris, France) or polylactide-co-glycolide (Vivitrol ${ }^{\circledR}$, Alkermes, Inc, Cambridge, MA; Depotrex ${ }^{\circledR}$, Biotek, Inc, Woburn, MA) have been clinically tested, with dosages ranging from 75 to $400 \mathrm{mg}$. ${ }^{40,66-68}$ The polylactide-co-glycolidepolymer formulation Vivitrol ${ }^{\mathbb{R}}$ containing $380 \mathrm{mg}$ of naltrexone received United States Food and Drug Administration (FDA) approval for treatment of alcohol dependence in April 2006 and for relapse prevention in OD patients after detoxification treatment in October $2010 .{ }^{69}$ This formulation releases naltrexone at levels above $1 \mathrm{ng} / \mathrm{mL}$ for about $4-5$ weeks, ${ }^{70}$ with no need to adjust the dosage to weight, age, gender, or health status. ${ }^{71}$

\section{Clinical studies}

Nonrandomized investigations have shown the ability of slow-release naltrexone injection to block opioid effects, ${ }^{72,73}$ and help maintain abstinence in different populations of OD patients, including adolescents. ${ }^{66,74}$

Three randomized, clinical studies have compared injectable naltrexone with oral naltrexone or placebo.

Comer et $\mathrm{al}^{75}$ studied the efficacy of extended-release injectable naltrexone for relapse prevention among heroindependent individuals in an RCT. Sixty patients were stratified 
by sex and years of heroin use and randomized to receive placebo, $192 \mathrm{mg}$, or $384 \mathrm{mg}$ of extended-release naltrexone intramuscular injections dosed on weeks 1 and 5. In addition to medication, patients received regular counseling. At the end of 2 months, $39 \%, 60 \%$, and $68 \%$ of the placebo, $192 \mathrm{mg}$ naltrexone, and $384 \mathrm{mg}$ naltrexone groups, respectively, were still in treatment. Mean treatment dropout occurred in 27 days, 36 days, and 48 days for the placebo, $192 \mathrm{mg}$ naltrexone, and $384 \mathrm{mg}$ naltrexone groups, respectively. Assuming that missing urine samples were positive, patients receiving placebo had the lowest mean percentage of negative urine samples (25.3\%), with the highest mean percentage of negative urine samples in the patient group receiving $384 \mathrm{mg}$ of naltrexone $(61.9 \%)$ and a significant main group effect $(P=0.03)$. Without that assumption, the treatment effect was no longer significant. Also, the number of patients retained in treatment did not show significant differences between groups. This lack of significance may have occurred because the study was not adequately powered, given the small sample size and three conditions of treatment.

Brooks et $\mathrm{al}^{76}$ utilizing a quasi-experimental uncontrolled design compared early treatment retention and opiate use confirmed by urine in OD patients in two concurrent randomized clinical trials of oral $(\mathrm{n}=69)$ and $192 \mathrm{mg}$ or $384 \mathrm{mg}$ extended-release injectable naltrexone $(\mathrm{n}=42)$. Patients receiving injectable naltrexone had higher mean days retained in treatment $(P=0.012)$, and patients with more severe heroin use had better treatment retention with oral naltrexone and therapy than extended-release injectable naltrexone and therapy. The therapeutic modalities employed in the two studies were different, and the authors attributed the improved retention in the severe heroin use group to the intensive psychosocial treatments received in addition to oral naltrexone.

Krupitsky et al completed a multisite RCT, and the results were reported by Gastfriend. ${ }^{69}$ In the study, monthly injections of extended-release naltrexone $380 \mathrm{mg}(\mathrm{n}=126)$ or placebo $(n=124)$ were combined with 12 biweekly sessions of drug counseling. Overall, the median patient taking extended-release naltrexone had confirmed abstinence during $90 \%$ of study weeks 5-24, compared to $35 \%$ for placebo $(P=0.0002)$. With extended-release naltrexone, $36 \%$ of patients maintained complete abstinence for weeks 5-24 vs $23 \%$ of placebo patients $(P=0.02)$. Naltrexone-treated patients also had significantly more self-reported opioid-free days $(P=0.0004)$, less craving $(P=0.0002)$, less relapse to physiological dependence as documented by positive naloxone challenge $(P<0.0001)$, longer median retention
( $P=0.004 ; 168$ days vs 96 days for placebo), and significant benefits on health outcomes, such as reduced human immunodeficiency virus (HIV) drug-risk behavior. Transaminases were more frequently elevated with extended-release naltrexone than placebo, but were isolated and transient, and there was no evidence of hepatic injury. Serious adverse events most commonly consisted of infectious processes, including autoimmunodeficiency syndrome/HIV, and were $2.4 \%$ among extended-release naltrexone patients and 3.2\% among placebo patients. No overdose events, suicide attempts, or deaths were reported.

\section{Clinical use of sustained-release naltrexone}

Although there is significant preliminary evidence of efficacy, the use of sustained-release formulations in association with relapse prevention therapy needs further research in large controlled trials with oral naltrexone and opioid agonist treatment, to improve the understanding on the role of the antagonist treatment for OD. At this point, we have found results of retrospective studies in limited samples suggesting that sustained-release naltrexone can reduce drug use and drug-related hospitalizations as much as methadone treatment does, ${ }^{60}$ or more. ${ }^{77}$ Moreover, the mortality profile in samples of patients treated with naltrexone implant is comparable to that of buprenorphine or methadone, or to the normal population. $23,78,79$

\section{Side effects}

Some common adverse effects such as nausea, vomiting, headache, fatigue, and muscle cramps show a degree of consistency between sustained-release formulations and oral naltrexone, ${ }^{80,81}$ and have been found to be mild to moderate. ${ }^{62,64,75}$ Although lower plasma concentrations and fewer peaks in the pharmacokinetic profile of naltrexone sustained-release formulations may justify a reduced intensity of adverse effects, direct comparisons of safety outcomes between implant or injection formulations and tablets are lacking. Local adverse effects such as pain, induration, infection, and allergic tissue reaction may occur when administering naltrexone injections or implants and were found to be more common among patients receiving naltrexone than placebo injections. ${ }^{75,82-84}$ Data on site-related adverse effects of naltrexone implants indicate a low rate of events, though they are scarce and mostly limited to single-group studies. ${ }^{52,85}$ Attempts at self-removal of naltrexone pellets can cause wounds, infections, and scarring and have not been ruled out in some cases. ${ }^{64}$ 
Naltrexone in all forms carries a black-box warning for hepatotoxicity, and warnings for use in patients with elevated hepatic enzymes and acute hepatitis, deriving from clinical reports on the use of oral naltrexone. Hepatotoxicity has been historically observed in obese patients and at oral doses about five-fold over the recommended dose ${ }^{86}$ Reports indicate that an interaction between nonsteroidal anti-inflammatory drugs (NSAIDs) and $>100 \mathrm{mg}$ oral naltrexone may lead to hepatotoxicity in alcohol-dependent subjects. ${ }^{87,88}$ Clinicians should be careful in administering high doses of naltrexone especially in the presence of comorbid alcohol- and opioid-use disorders and should warn patients of such potentially dangerous drug interaction. In large trials of alcohol-dependent patients who were administered slowrelease injectable naltrexone or placebo, the existence of high risk individuals among heavy drinkers, obese patients, and those taking NSAIDS was confirmed, though no increase in hepatic enzymes or hepatic-related adverse events was found with injectable naltrexone compared to placebo. ${ }^{84,89}$ Further studies in patients with alcohol-induced liver impairment failed to detect naltrexone injection-associated worsening of liver function. ${ }^{40}$ In a case report of an OD patient presenting with acute hepatitis during treatment with a 1-g naltrexone implant, naltrexone did not affect the patient's recovery. ${ }^{90}$

\section{Limitations}

Some characteristics of the treatment with sustained-release naltrexone may affect its widespread clinical use.

\section{Administration and cost}

Modalities of preserving and administering the slow-release naltrexone formulations require a 'set-up' and the coordinated effort of several physicians, including psychiatrist, internist, and anesthesiologist. In some countries, the cost of depot naltrexone may significantly surpass that of the oral formulation. For example, the cost per day of the FDAapproved extended-release naltrexone formulation is $10-15$ times higher than that of the oral preparation. This could affect the choice of treatment, though cost-effective analysis may confirm significantly reduced health care expenses using depot naltrexone for OD, as already demonstrated in alcohol dependence. ${ }^{91}$

\section{Naltrexone induction}

The common methods of controlling withdrawal and safe transfer of OD patients to naltrexone are expensive and time consuming and may contribute to its reduced use. ${ }^{19} \mathrm{In}$ accordance with oral naltrexone, OD patients are induced to clinically-approved long-acting NTX formulations usually after inpatient detoxification and should remain opioid-free for a minimum of $7-10$ days $\left(\right.$ Vivitrol $^{\circledR}$ insert package). These measures aim at preventing the onset of intense withdrawal that could be difficult to treat because of the long-lasting effects of sustained-release naltrexone, though require conditions of treatment that are not easily accessible. In addition, having patients wait increases chances of vulnerability to drug use and drop out. ${ }^{92}$ Existing approaches using different sedation techniques or naltrexone titration methods to ease the transfer needs replication and/or wider availability. ${ }^{93-95} \mathrm{New}$ safe methods to reduce time and discomfort of the transition are warranted.

\section{Risk of overdose}

The risk of death related to oral naltrexone appears higher than that associated with methadone treatment. ${ }^{96}$ Deaths and overdoses have been reported during long-acting naltrexone treatment and following its discontinuation. ${ }^{59,97,98} \mathrm{~A}$ consistent and prolonged dosing exposure using sustained-release naltrexone may contribute to enhance the $\mu$ receptor sensitivity to opioids of an abstinent individual previously tolerant to larger doses of opiates. There are retrospective data showing no significant increase in overdose-related deaths with depot formulations,${ }^{79}$ but attempts of self-testing the competitive antagonist blockade have been reported. ${ }^{56,72}$ Therefore, longitudinal controlled studies are needed. Patients starting treatment with naltrexone need to be carefully advised of the risks of overdose with opiates during treatment with naltrexone, as well as after discontinuation.

\section{Management of pain}

Management of intense pain during treatment with sustainedrelease naltrexone requires a multidisciplinary team and may be not possible in an outpatient setting, as adequate analgesia would not be attainable with oral opioids. Patient cases are reported where nonopioid analgesics or a regional nerve blockade were used and provided effective analgesia. ${ }^{99}$ If opioid therapy is required as part of anesthesia or analgesia, patients should be monitored in an anesthesia care setting by personnel trained in the use of anesthetic drugs and in the management of the respiratory effects of potent opioids, including the establishment and maintenance of a patent airway, assisted ventilation, and cardiopulmonary resuscitation.

\section{Pharmacological combinations}

The initial use of medications in combination with naltrexone to ease opioid withdrawal ${ }^{100}$ has in some cases extended to supporting antagonist maintenance therapy and suggests 
the opportunity to further study mixed receptor activities and their application to the treatment of OD and other addictions.

\section{Naltrexone and serotonin reuptake inhibitors (SSRIs)}

Landabaso et a ${ }^{101}$ administered fluoxetine to 112 detoxified heroin users newly admitted to naltrexone treatment and found that patients randomized to receive the medication showed a significantly higher retention rate in treatment at 6 and 12 months than controls. In a subsequent RCT of 280 OD patients, ${ }^{102}$ adding fluoxetine to naltrexone did not further improve the already significant increases in treatment retention and opioid abstinence after 6 months in patients treated with the opioid antagonist agent, compared with naltrexone placebo. However, the results were close to significance among women receiving naltrexone and fluoxetine compared with those receiving naltrexone and fluoxetine placebo. Fluoxetine alone was not superior to placebo for relapse prevention, although it was associated with twice as many patients who remained in treatment. In a study of 98 OD patients by Gerra et al, ${ }^{103}$ the administration of fluoxetine with naltrexone was associated with reduced craving, hostility, and relapse in a subgroup of patients with high inward hostility, late onset of the disease, and preference for heroin and alcohol, as opposed to those with outward hostility, legal problems, and heroine-cocaine preference, or to control opioid abusers with no 'serotonergic system sensitivity'. Additionally, Farren and O'Malley ${ }^{104}$ conducted an RCT of naltrexone in combination with sertraline in $13 \mathrm{OD}$ patients. The combination therapy was associated with an initial increase of retention in treatment relative to naltrexone alone, but the effect diminished over 3 months.

\section{Naltrexone and presynaptic $\alpha$-adrenergic agonists}

In an open-label, single-blind pilot study by Sinha et al, ${ }^{105}$ 18 opioid-detoxified patients received naltrexone $(50 \mathrm{mg})$ and lofexidine (2.4 mg) daily for 1 month. Patients were then continued on naltrexone for 4 more weeks and eight of them were kept on lofexidine, while 10 others received identicallooking pills containing lofexidine doses that were tapered off over several days. Of the 13 patients who completed the study, $80 \%$ of those who continued to receive combination therapy submitted opiate-free urine samples throughout the 4-week period, compared with $25 \%$ of those tapered to placebo. A follow-up laboratory session that exposed 10 patients to stressful and opiate-related stimuli showed that lofexidine, but not placebo lofexidine, reduced the patients' reaction to stress, stress-induced opiate craving, and negative emotions, all of which are associated with relapse. Presently, an ongoing large $(\mathrm{n}=300)$ RCT is studying the combination of naltrexone and guanfacine (another presynaptic $\alpha-2$ adrenergic agonist). An interim analysis of half of the sample has not found a significant additive effect of guanfacine on preventing relapse. ${ }^{65}$

\section{Naltrexone and opioid agonists}

The combined administration of buprenorphine $4 \mathrm{mg}$ sublingual and naltrexone $50 \mathrm{mg}$ oral following opioid detoxification has been tested in two clinical investigations. In a nonrandomized 3-month observational study, ${ }^{106}$ Gerra et al showed that retention rates in 30 patients receiving naltrexone and 30 receiving naltrexone + buprenorphine at 3 months were $40 \%$ (12 patients) and $73.33 \%$ (22 patients), respectively. Patients treated with naltrexone in combination with buprenorphine showed a significantly lower rate of positive urines for opioids (4.45\%) and cocaine metabolites $(9.09 \%)$ than those treated with naltrexone alone (25\% opioids; $33.33 \%$ cocaine). Behavioral and psychological symptoms, such as craving, irritability, and depression, were also improved in the buprenorphine/naltrexone group. The same combination of medications was previously investigated by Rothman et $\mathrm{l}^{107}$ in 15 OD subjects following detoxification. Although the absence of a "naltrexone only" group precluded any firm conclusion, abstinence and retention rates were not dissimilar to those described by Gerra et al.

\section{Naltrexone and $\gamma$-aminobutyric acid (GABA) agonists}

Stella et a ${ }^{108}$ evaluated whether NTX combined with the benzodiazepine prazepam was more effective than NTX in preventing relapse in a 6-month study. Fifty-six OD subjects were randomized to receive naltrexone and prazepam $(10 \mathrm{mg}$ twice a day) or placebo with psychosocial treatment, naltrexone with psychosocial treatment, and psychosocial treatment alone. All groups underwent drug urine tests twice weekly. By the end of the study, a significant higher number of patients receiving naltrexone in combination with prazepam had remained opioid-free (85.7\%) compared with those receiving naltrexone and placebo or naltrexone alone (both $42.9 \%$ ), or counseling only (21.4\%). Additionally, more patients receiving the combination treatment were cannabis-free. The authors suggested that the addition of a GABA agonist medication (eg, prazepam) may significantly improve relapse prevention during naltrexone treatment of OD patients. 


\section{Rationale on the clinical use of combination treatments}

Small pilot studies suggest the feasibility to further explore the effects of the addition of various medications to naltrexone. Considerations on the pharmacological rationale for each medication group follow.

\section{Antidepressants}

The use of antidepressants in combination with opioid agonist medications is relatively common in clinical practice, but has not been found to effectively reduce drug abuse or favor retention in treatment among depressed patients. ${ }^{109}$ SSRIs or other antidepressants may help manage stress in nondepressed OD individuals and address depressive symptoms, irritability, and dysphoria commonly associated with craving and relapse during naltrexone induction and early stabilization. ${ }^{10}$

\section{$\alpha-2$ agonists}

Increased stress levels and stress-induced opioid cravings following discontinuation of opioid agonist medications is not consistently controlled during naltrexone therapy. ${ }^{11,112} \alpha-2$ adrenergic agonist medications that have been administered to reduce hyperadrenergic activity during opioid withdrawal, such as clonidine, lofexidine, and guanfacine, also display discriminative stimulus effects and reinforcing properties in animals, ${ }^{113,114}$ and may be used to improve long-term naltrexone outcomes, if the associated orthostatic hypotension can be controlled.

\section{Opioid agonists}

Alcohol and nonopioid drug use as well as associated morbidity are significant unresolved problems in naltrexone maintenance treatment. ${ }^{77}$ Rothman and co-workers ${ }^{107}$ first proposed the combination naltrexone/buprenorphine as a functional $\kappa$-opioid receptor antagonist to help overcome dysphoric symptoms associated with prolonged opioid withdrawal discomfort and cocaine use. Buprenorphine shows strong $\kappa$ - and $\delta$-opioid receptor affinity that reinforces naltrexone's weak antagonist action, associated with unique significant agonism at the nociceptin receptor (ORL-1) (Table 1). The mixed receptor activity of this combination justifies its effects not only on dysphoric mood and opioidseeking behavior and use, but also on cocaine and alcohol abuse. ${ }^{115}$ Other opioid agonist/antagonist combinations, using extremely low dose naltrexone with methadone, have shown the potential to reduce opioid withdrawal and physical dependence, ${ }^{116}$ which may help in the early induction phase to naltrexone maintenance.

\section{GABA agonists}

GABA-glutamate imbalance is thought to play a role in the development and expression of sleeping disorders, anxiety, and drug abuse/withdrawal. ${ }^{117-119}$ Insomnia and anxiety are common symptoms in naltrexone-treated OD patients ${ }^{31}$ and have been noted to last through naltrexone induction and stabilization. ${ }^{120}$ The use of a medication resulting in net GABA agonism and lacking the abuse liability displayed by benzodiazepines may help control specific behavioral problems associated with anxiety and insomnia during naltrexone treatment. One example is the ongoing experimentation with the N-methyl-D-aspartate-glutamate receptor antagonist memantine in addition to naltrexone injection in OD patients (ClinicalTrials.gov identifier NCT00476242). GABA receptor agonists, such as baclofen, vigabatrin, tiagabine, and gabapentin, have shown potential utility as adjunct treatments for OD and withdrawal, ${ }^{121-125}$ though no data on their use with naltrexone are available.

Other drug mechanisms that contribute to reduced opioid withdrawal severity and may produce a complementary or synergistic effect with opioid antagonists remain untested in OD. For example, corticotropin-releasing factor type 1 receptor antagonists appear to regulate stress-induced drug taking behavior that can be paired to the basal control exerted by naltrexone in alcohol-dependent animals, ${ }^{126}$ whereas the glutamate partial agonist D-cycloserine has shown conditioned opioid stimuli extinction characteristics in animals, ${ }^{127}$ which may reinforce the extinction properties of naltrexone treatment.

Safety data on pharmacological combinations using naltrexone in OD individuals are limited. Although the studies we have reviewed for this paper did not report significant adverse events, available information from other sources is scarce. ${ }^{128,129}$

Finally, a better characterization of individual phenotypes, perhaps using a pharmacogenetic approach, may help recognize subgroups of patients who can benefit from mixed pharmacological actions. One example is offered by the ongoing efforts to identify biological endophenotypes for naltrexone and acamprosate in the management of alcohol dependence that may lead to preselect potential responders to their combination. ${ }^{130,131}$

\section{Conclusion}

Several studies, including RCTs, suggest that the use of naltrexone depot formulations in OD patients leads to significant reductions in opioid use and improved treatment retention. The consistent evidence from uncontrolled investigations 
can serve as a path-finding experience. More importantly, larger, multicenter RCTs to measure the effectiveness of the treatment and trials comparing slow-release naltrexone with naltrexone tablets or agonist maintenance treatment are needed to confirm the initial findings and provide prospective data on patient safety and tolerability, characterizing the role of opioid antagonist treatment in OD. Previous experiences using long-acting formulations in the treatment of other psychiatric conditions such as schizophrenia have shown that this method can improve effectiveness of, ${ }^{132}$ acceptance of, and adherence to treatment, ${ }^{133}$ significantly reducing the burden of disease. ${ }^{134}$ Pilot studies combining naltrexone with other medications also suggest possible mechanisms that warrant further research to improve outcomes of OD treatment. Available techniques, such as pharmacogenetics, can help identify specific endophenotypes and find a better treatment match for patients. In conclusion, improving naltrexone outcome would expand the therapeutic options for OD and offer continuity of care to those patients who cannot access or choose not to initiate opioid agonist substitution therapy, and to many others when they discontinue methadone or buprenorphine treatment.

\section{Acknowledgments}

This paper was made possible in part by the United States National Institute on Drug Abuse of the National Institutes of Health (DA15469, DA019901). Its contents are solely the responsibility of the authors and do not necessarily represent the official views of the National Institutes of Health. The National Institutes of Health had no role in the preparation, review, or approval of this manuscript.

\section{Disclosure}

P Mannelli has received support from the following: AstraZeneca, Bristol-Myers Squibb, Cephalon, Inc, Forest, GlaxoSmithKline, Janssen, Jazz Pharmaceuticals, King Pharmaceutical, Lundbeck, McNeil Consumer and Specialty, Merck, Organon, Orphan Medical, Pfizer, Reckitt Benckiser, and Titan. KS Peindl and LT Wu have no conflicts of interest to disclose.

\section{References}

1. Paulozzi L, Budnitz D, Xi Y. Increasing deaths from opioid analgesics in the United States. Pharmacoepidemiol Drug Saf. 2006;15(9):619-627.

2. Substance Abuse and Mental Health Services Administration (SAMHSA). Results from the 2009 national survey on drug use and health: volume I. Summary of national findings. Rockville, MD: Office of Applied Studies, NSDUH; 2010.

3. Friedmann PD, Lemon SC, Stein MD, D'Aunno TA. Accessibility of addiction treatment: results from a national survey of outpatient substance abuse treatment organizations. Health Serv Res. 2003;38(3):887-903.
4. Peterson JA, Schwartz RP, Mitchell SG, et al. Why don't out-oftreatment individuals enter methadone treatment programmes? Int $J$ Drug Policy. 2010;21(1):36-42.

5. Caplehorn JR, Hartel DM, Irwig L. Measuring and comparing the attitudes and beliefs of staff working in New York methadone maintenance clinics. Subst Use Misuse. 1997;32(4):399-413.

6. Schwartz RP, Kelly SM, O'Grady KE, et al. Attitudes toward buprenorphine and methadone among opioid-dependent individuals. Am JAddict. 2008;17(5):396-401.

7. Zaller ND, Bazazi AR, Velazquez L, Rich JD. Attitudes toward methadone among out-of-treatment minority injection drug users: implications for health disparities. Int J Environ Res Public Health. 2009;6(2):787-797.

8. Reece A. Differing age related trajectories of dysfunction in several organ systems in opiate dependence. Aging Clin Exp Res. February 21, 2011. [Epub ahead of print].

9. Reece A, Davidson P. Deficit of circulating stem - progenitor cells in opiate addiction: a pilot study. Subst Abuse Treat Prev Policy. 2007;2:19.

10. Toskulkao T, Pornchai R, Akkarapatumwong V, Vatanatunyakum S, Govitrapong P. Alteration of lymphocyte opioid receptors in methadone maintenance subjects. Neurochem Int. 2010;56(2):285-290.

11. Ling W, Wesson DR. Clinical efficacy of buprenorphine: comparisons to methadone and placebo. Drug Alcohol Depend. 2003; 70(2 Suppl):S49-S57.

12. Stenbacka M, Beck O, Leifman A, Romelsjo A, Helander A. Problem drinking in relation to treatment outcome among opiate addicts in methadone maintenance treatment. Drug Alcohol Rev. 2007;26(1): $55-63$.

13. Reece A. Hypothalamic opioid-melanocortin appetitive balance and addictive craving. Med Hypotheses. 2011;76(1):132-137.

14. Adi Y, Juarez-Garcia A, Wang D, et al. Oral naltrexone as a treatment for relapse prevention in formerly opioid-dependent drug users: a systematic review and economic evaluation. Health Technol Assess. 2007;11(6):iii-iv, 1-85.

15. Gonzalez G, Oliveto A, Kosten TR. Combating opiate dependence: a comparison among the available pharmacological options. Expert Opin Pharmacother. 2004;5(4):713-725.

16. Minozzi S, Amato L, Davoli M. Detoxification treatments for opiate dependent adolescents. Cochrane Database Syst Rev. 2009;15(2):CD006749.

17. Wikler A. Requirements for extinction of relapse-facilitating variables and for rehabilitation in a narcotic-antagonist treatment program. $A d v$ Biochem Psychopharmacol. 1973;8(0):399-414.

18. Cornish JW, Metzger D, Woody GE, et al. Naltrexone pharmacotherapy for opioid dependent federal probationers. J Subst Abuse Treat. 1997;14(6):529-534.

19. Kleber HD. Pharmacologic treatments for opioid dependence: detoxification and maintenance options. Dialogues Clin Neurosci. 2007;9(4):455-470.

20. O'Brien C, Cornish JW. Naltrexone for probationers and parolees. J Subst Abuse Treat. 2006;31(2):107-111.

21. Washton AM, Gold MS, Pottash AC. Successful use of naltrexone in addicted physicians and business executives. Adv Alcohol Subst Abuse. 1984;4(2):89-96.

22. Brewer C, Streel E. Learning the language of abstinence in addiction treatment: some similarities between relapse-prevention with disulfiram, naltrexone, and other pharmacological antagonists and intensive "immersion" methods of foreign language teaching. Subst Abus. 2003;24(3):157-173.

23. Reece AS. Psychosocial and treatment correlates of opiate free success in a clinical review of a naltrexone implant program. Subst Abuse Treat Prev Policy. 2007;2:35.

24. Fram DH, Marmo J, Holden R. Naltrexone treatment - the problem of patient acceptance. J Subst Abuse Treat. 1989;6(2):119-122.

25. Tennant FS Jr, Rawson RA, Cohen AJ, Mann A. Clinical experience with naltrexone in suburban opioid addicts. J Clin Psychiatry. 1984;45(9 Pt 2): $42-45$. 
26. Greenstein RA, O'Brien CP, McLellan AT, et al. Naltrexone: a shortterm treatment for opiate dependence. Am J Drug Alcohol Abuse. 1981;8(3):291-300.

27. Crowley TJ, Wagner JE, Zerbe G, Macdonald M. Naltrexoneinduced dysphoria in former opioid addicts. Am J Psychiatry. 1985; 142(9):1081-1084.

28. Hollister LE, Johnson K, Boukhabza D, Gillespie HK. Aversive effects of naltrexone in subjects not dependent on opiates. Drug Alcohol Depend. 1981;8(1):37-41.

29. Dean AJ, Saunders JB, Jones RT, Young RM, Connor JP, Lawford BR. Does naltrexone treatment lead to depression? Findings from a randomized controlled trial in subjects with opioid dependence. J Psychiatry Neurosci. 2006;31(1):38-45.

30. Miotto K, McCann M, Basch J, Rawson R, Ling W. Naltrexone and dysphoria: fact or myth? Am J Addict. 2002;11(2):151-160.

31. Mysels DJ, Cheng WY, Nunes EV, Sullivan MA. The association between naltrexone treatment and symptoms of depression in opioiddependent patients. Am J Drug Alcohol Abuse. 2011;37(1):22-26.

32. Carroll KM, Ball SA, Nich C, et al. Targeting behavioral therapies to enhance naltrexone treatment of opioid dependence: efficacy of contingency management and significant other involvement. Arch Gen Psychiatry. 2001;58(8):755-761.

33. Preston KL, Silverman K, Umbricht A, DeJesus A, Montoya ID, Schuster CR. Improvement in naltrexone treatment compliance with contingency management. Drug Alcohol Depend. 1999;54(2): $127-135$.

34. Nunes EV, Rothenberg JL, Sullivan MA, Carpenter KM, Kleber HD. Behavioral therapy to augment oral naltrexone for opioid dependence: a ceiling on effectiveness? Am J Drug Alcohol Abuse. 2006 32(4):503-517.

35. Oslin DW, Lynch KG, Pettinati HM, et al. A placebo-controlled randomized clinical trial of naltrexone in the context of different levels of psychosocial intervention. Alcohol Clin Exp Res. 2008; 32(7):1299-1308.

36. Sullivan MA, Garawi F, Bisaga A, et al. Management of relapse in naltrexone maintenance for heroin dependence. Drug Alcohol Depend. 2007;91(2-3):289-292.

37. Martin WR, Jasinski DR, Mansky PA. Naltrexone, an antagonist for the treatment of heroin dependence. Effects in man. Arch Gen Psychiatry. 1973;28(6):784-791.

38. O’Brien CP, Greenstein RA, Mintz J, Woody GE. Clinical experience with naltrexone. Am J Drug Alcohol Abuse. 1975;2(3-4):365-377.

39. Licko V. Overview of human pharmacokinetics of naltrexone. NIDA Res Monogr. 1981;28:161-171.

40. Turncliff RZ, Dunbar JL, Dong Q, et al. Pharmacokinetics of long-acting naltrexone in subjects with mild to moderate hepatic impairment. J Clin Pharmacol. 2005;45(11):1259-1267.

41. McCaul ME, Wand GS, Rohde C, Lee SM. Serum 6-beta-naltrexol levels are related to alcohol responses in heavy drinkers. Alcohol Clin Exp Res. 2000;24(9):1385-1391.

42. Lee MC, Wagner HN Jr, Tanada S, Frost JJ, Bice AN, Dannals RF. Duration of occupancy of opiate receptors by naltrexone. J Nucl Med. 1988;29(7):1207-1211.

43. Verebey K, Volavka J, Mule SJ, Resnick RB. Naltrexone: disposition, metabolism, and effects after acute and chronic dosing. Clin Pharmacol Ther. 1976;20(3):315-328.

44. Koob GF, Le Moal M. Addiction and the brain antireward system. Annu Rev Psychol. 2008;59:29-53.

45. Stromberg MF, Sengpiel T, Mackler SA, Volpicelli JR, O`Brien CP, Vogel WH. Effect of naltrexone on oral consumption of concurrently available ethanol and cocaine in the rat. Alcohol. 2002;28(3): 169-179.

46. Schmidt WK, Tam SW, Shotzberger GS, Smith DH Jr, Clark R, Vernier VG. Nalbuphine. Drug Alcohol Depend. 1985;14(3-4):339-362.

47. McLeod RL, Parra LE, Mutter JC, et al. Nociceptin inhibits cough in the guinea-pig by activation of ORL(1) receptors. Br J Pharmacol. 2001;132(6):1175-1178.
48. Wnendt S, Kruger T, Janocha E, Hildebrandt D, Englberger W. Agonistic effect of buprenorphine in a nociceptin/OFQ receptor-triggered reporter gene assay. Mol Pharmacol. 1999;56(2):334-338.

49. Olsen L, Christophersen AS, Frogopsahl G, Waal H, Morland J. Plasma concentrations during naltrexone implant treatment of opiate-dependent patients. Br J Clin Pharmacol. 2004;58(2):219-222.

50. Ramenskaya G, Shikh E, Arzamastsev A, Kukes V. Molecular biological problems of drug design and mechanism of drug action. Pharmacokinetic study of the new domestic hypodermic formof naltrexone: prodetoxon depot tablets. Pharm Chem J. 2005;39(1): $1-3$.

51. Ngo HT, Arnold-Reed DE, Hansson RC, Tait RJ, Hulse GK. Blood naltrexone levels over time following naltrexone implant. Prog Neuropsychopharmacol Biol Psychiatry. 2008;32(1):23-28.

52. Waal H, Frogopsahl G, Olsen L, Christophersen AS, Morland J. Naltrexone implants - duration, tolerability and clinical usefulness. A pilot study. Eur Addict Res. 2006;12(3):138-144.

53. Colquhoun R, Tan DY, Hull S. A comparison of oral and implant naltrexone outcomes at 12 months. J Opioid Manag. 2005;1(5): 249-256.

54. Foster J, Brewer C, Steele T. Naltrexone implants can completely prevent early (1-month) relapse after opiate detoxification: a pilot study of two cohorts totalling 101 patients with a note on naltrexone blood levels. Addict Biol. 2003;8(2):211-217.

55. Hulse GK, Arnold-Reed DE, O'Neil G, Chan CT, Hansson R, O'Neil P. Blood naltrexone and 6-beta-naltrexol levels following naltrexone implant: comparing two naltrexone implants. Addict Biol. 2004;9(1): 59-65.

56. Krupitsky EM, Burakov AM, Dunaevsky IV, Romanova TN, Slavina TY, Grinenko AY. Single versus repeated sessions of ketamine-assisted psychotherapy for people with heroin dependence. J Psychoactive Drugs. 2007;39(1):13-19.

57. Carreno JE, Alvarez CE, Narciso GI, Bascaran MT, Diaz M, Bobes J. Maintenance treatment with depot opioid antagonists in subcutaneous implants: an alternative in the treatment of opioid dependence. Addict Biol. 2003;8(4):429-438.

58. Kunoe N, Lobmaier P, Vederhus JK, et al. Retention in naltrexone implant treatment for opioid dependence. Drug Alcohol Depend. 2010;111(1-2):166-169.

59. Lintzeris N, Lee S, Scopelliti L, Mabbutt J, Haber PS. Unplanned admissions to two Sydney public hospitals after naltrexone implants. Med J Aust. 2008;188(8):441-444.

60. Lobmaier PP, Kunoe N, Gossop M, Katevoll T, Waal H. Naltrexone implants compared to methadone: outcomes six months after prison release. Eur Addict Res. 2010;16(3):139-145.

61. Ngo HT, Tait RJ, Arnold-Reed DE, Hulse GK. Mental health outcomes following naltrexone implant treatment for heroin-dependence. Prog Neuropsychopharmacol Biol Psychiatry. 2007;31(3):605-612.

62. Hulse GK, Morris N, Arnold-Reed D, Tait RJ. Improving clinical outcomes in treating heroin dependence: randomized, controlled trial of oral or implant naltrexone. Arch Gen Psychiatry. 2009;66(10): 1108-1115.

63. Hulse GK, Ngo HT, Tait RJ. Risk factors for craving and relapse in heroin users treated with oral or implant naltrexone. Biol Psychiatry. 2010;68(3):296-302.

64. Kunoe N, Lobmaier P, Vederhus JK, et al. Naltrexone implants after in-patient treatment for opioid dependence: randomised controlled trial. Br J Psychiatry. 2009;194(6):541-546.

65. Krupitsky E, Zvartau E, Woody G. Use of naltrexone to treat opioid addiction in a country in which methadone and buprenorphine are not available. Curr Psychiatry Rep. 2010;12(5):448-453.

66. Comer SD, Collins ED, Kleber HD, Nuwayser ES, Kerrigan JH, Fischman MW. Depot naltrexone: long-lasting antagonism of the effects of heroin in humans. Psychopharmacology (Berl). 2002;159(4): $351-360$.

67. Galloway GP, Koch M, Cello R, Smith DE. Pharmacokinetics, safety, and tolerability of a depot formulation of naltrexone in alcoholics: an open-label trial. BMC Psychiatry. 2005;5:18. 
68. Johnson BA. Naltrexone long-acting formulation in the treatment of alcohol dependence. Ther Clin Risk Manag. 2007;3(5):741-749.

69. Gastfriend DR. Intramuscular extended-release naltrexone: current evidence. Ann N Y Acad Sci. 2011;1216:144-166.

70. Dunbar JL, Turncliff RZ, Dong Q, Silverman BL, Ehrich EW, Lasseter KC. Single- and multiple-dose pharmacokinetics of longacting injectable naltrexone. Alcohol Clin Exp Res. 2006;30(3): 480-490.

71. Dunbar JL, Turncliff RZ, Hayes SC, Farrell CB. Population pharmacokinetics of extended-release injectable naltrexone (XR-NTX) in patients with alcohol dependence. J Stud Alcohol Drugs. 2007;68(6): 862-870.

72. Fishman M. Precipitated withdrawal during maintenance opioid blockade with extended release naltrexone. Addiction. 2008;103(8): 1399-1401.

73. Sullivan MA, Rothenberg JL, Vosburg SK, et al. Predictors of retention in naltrexone maintenance for opioid dependence: analysis of a stage I trial. Am J Addict. 2006;15(2):150-159.

74. Fishman MJ, Winstanley EL, Curran E, Garrett S, Subramaniam G. Treatment of opioid dependence in adolescents and young adults with extended release naltrexone: preliminary case-series and feasibility. Addiction. 2010;105(9):1669-1676.

75. Comer SD, Sullivan MA, Yu E, et al. Injectable, sustained-release naltrexone for the treatment of opioid dependence: a randomized, placebo-controlled trial. Arch Gen Psychiatry. 2006;63(2): 210-218.

76. Brooks AC, Comer SD, Sullivan MA, et al. Long-acting injectable versus oral naltrexone maintenance therapy with psychosocial intervention for heroin dependence: a quasi-experiment. J Clin Psychiatry. 2010;71(10):1371-1378.

77. Ngo HT, Tait RJ, Hulse GK. Comparing drug-related hospital morbidity following heroin dependence treatment with methadone maintenance or naltrexone implantation. Arch Gen Psychiatry. 2008;65(4):457-465.

78. Reece AS. Comparative treatment and mortality correlates and adverse event profile of implant naltrexone and sublingual buprenorphine. J Subst Abuse Treat. 2009;37(3):256-265.

79. Tait RJ, Ngo HT, Hulse GK. Mortality in heroin users 3 years after naltrexone implant or methadone maintenance treatment. J Subst Abuse Treat. 2008;35(2):116-124.

80. Oncken C, Van Kirk J, Kranzler HR. Adverse effects of oral naltrexone: analysis of data from two clinical trials. Psychopharmacology (Berl). 2001;154(4):397-402.

81. Lobmaier P, Kornor H, Kunoe N, Bjorndal A. Sustained-release naltrexone for opioid dependence. Cochrane Database Syst Rev. 2008;16(2):CD006140.

82. Garbutt JC, Kranzler HR, O'Malley SS, et al. Efficacy and tolerability of long-acting injectable naltrexone for alcohol dependence: a randomized controlled trial. JAMA. 2005;293(13):1617-1625.

83. Johnson BA, Ait-Daoud N, Aubin HJ, et al. A pilot evaluation of the safety and tolerability of repeat dose administration of long-acting injectable naltrexone (Vivitrex) in patients with alcohol dependence. Alcohol Clin Exp Res. 2004;28(9):1356-1361.

84. Kranzler HR, Wesson DR, Billot L; DrugAbuse Sciences Naltrexone Depot Study Group. Naltrexone depot for treatment of alcohol dependence: a multicenter, randomized, placebo-controlled clinical trial. Alcohol Clin Exp Res. 2004;28(7):1051-1059.

85. Hulse GK, Stalenberg V, McCallum D, et al. Histological changes over time around the site of sustained release naltrexone-poly(DL-lactide) implants in humans. $J$ Control Release. 2005;108(1):43-55.

86. Croop RS, Faulkner EB, Labriola DF. The safety profile of naltrexone in the treatment of alcoholism. Results from a multicenter usage study. The Naltrexone Usage Study Group. Arch Gen Psychiatry. 1997;54(12):1130-1135.

87. Kim SW, Grant JE, Adson DE, Remmel RP. A preliminary report on possible naltrexone and nonsteroidal analgesic interactions. $J$ Clin Psychopharmacol. 2001;21(6):632-634.
88. Kim SW, Grant JE, Yoon G, Williams KA, Remmel RP. Safety of high-dose naltrexone treatment: hepatic transaminase profiles among outpatients. Clin Neuropharmacol. 2006;29(2):77-79.

89. Lucey MR, Silverman BL, Illeperuma A, O’Brien CP. Hepatic safety of once-monthly injectable extended-release naltrexone administered to actively drinking alcoholics. Alcohol Clin Exp Res. 2008; 32(3):498-504.

90. Brewer C, Wong VS. Naltrexone: report of lack of hepatotoxicity in acute viral hepatitis, with a review of the literature. Addict Biol. 2004;9(1):81-87.

91. Mark T, Montejano L, Kranzler H, Chalk M, Gastfriend D. Comparison of healthcare utilization among patients treated with alcoholism medications. Am J Manag Care. 2010;16(12):879-888.

92. Kosten TR, Kleber HD. Strategies to improve compliance with narcotic antagonists. Am J Drug Alcohol Abuse. 1984;10(2):249-266.

93. Mannelli P, Gottheil E, Buonanno A, De Risio S. Use of very lowdose naltrexone during opiate detoxification. J Addict Dis. 2003; 22(2):63-70

94. Mannelli P, Patkar AA, Peindl K, Murray HW, Wu LT, Hubbard R. Effectiveness of low-dose naltrexone in the post-detoxification treatment of opioid dependence. J Clin Psychopharmacol. 2007;27(5): 468-474.

95. O'Connor PG, Kosten TR. Rapid and ultrarapid opioid detoxification techniques. JAMA. 1998;279(3):229-234.

96. Gibson AE, Degenhardt LJ. Mortality related to pharmacotherapies for opioid dependence: a comparative analysis of coronial records. Drug Alcohol Rev. 2007;26(4):405-410.

97. Gibson AE, Degenhardt LJ, Hall WD. Opioid overdose deaths can occur in patients with naltrexone implants. Med J Aust. 2007;186(3):152-153.

98. Oliver P, Horspool M, Keen J. Fatal opiate overdose following regimen changes in naltrexone treatment. Addiction. 2005;100(4):560-561.

99. O'Brien B, Cody C. Analgesia and sedation in the presence of a naltrexone implant: a novel pharmacological challenge. Eur J Emerg Med. 2006;13(5):315-316.

100. Stine SM, Kosten TR. Use of drug combinations in treatment of opioid withdrawal. J Clin Psychopharmacol. 1992;12(3):203-209.

101. Landabaso MA, Iraurgi I, Jimenez-Lerma JM, et al. A randomized trial of adding fluoxetine to a naltrexone treatment programme for heroin addicts. Addiction. 1998;93(5):739-744.

102. Krupitsky EM, Zvartau EE, Masalov DV, et al. Naltrexone with or without fluoxetine for preventing relapse to heroin addiction in St Petersburg, Russia. J Subst Abuse Treat. 2006;31(4):319-328.

103. Gerra G, Fertonani G, Zaimovic A, et al. Hostility in heroin abusers subtypes: fluoxetine and naltrexone treatment. Prog Neuropsychopharmacol Biol Psychiatry. 1995;19(8):1225-1237.

104. Farren CK, O'Malley S. A pilot double blind placebo controlled trial of sertraline with naltrexone in the treatment of opiate dependence. Am J Addict. 2002;11(3):228-234.

105. Sinha R, Kimmerling A, Doebrick C, Kosten TR. Effects of lofexidine on stress-induced and cue-induced opioid craving and opioid abstinence rates: preliminary findings. Psychopharmacology (Berl). 2007;190(4):569-574.

106. Gerra G, Fantoma A, Zaimovic A. Naltrexone and buprenorphine combination in the treatment of opioid dependence. $J$ Psychopharmacol. 2006;20(6):806-814.

107. Rothman RB, Gorelick DA, Heishman SJ, et al. An open-label study of a functional opioid kappa antagonist in the treatment of opioid dependence. J Subst Abuse Treat. 2000;18(3):277-281.

108. Stella L, D'Ambra C, Mazzeo F, et al. Naltrexone plus benzodiazepine aids abstinence in opioid-dependent patients. Life Sci. 2005;77(21):2717-2722.

109. Pani PP, Trogu E, Vacca R, Amato L, Vecchi S, Davoli M. Disulfiram for the treatment of cocaine dependence. Cochrane Database Syst Rev. 2010;20(1):CD007024.

110. Kleber HD, Kosten TR. Naltrexone induction: psychologic and pharmacologic strategies. J Clin Psychiatry. 1984;45(9 Pt 2):29-38. 
111. Dijkstra BA, De Jong CA, Bluschke SM, Krabbe PF, van der Staak CP. Does naltrexone affect craving in abstinent opioid-dependent patients? Addict Biol. 2007;12(2):176-182.

112. Hyman SM, Hong KI, Chaplin TM, et al. A stress-coping profile of opioid dependent individuals entering naltrexone treatment: a comparison with healthy controls. Psychol Addict Behav. 2009;23(4):613-619.

113. Bennett D, Lal H. Discriminative stimuli produced by clonidine: an investigation of the possible relationship to adrenoceptor stimulation and hypotension. J Pharmacol Exp Ther. 1982;223(3):642-648.

114. Weerts E, Griffiths R. Evaluation of the intravenous reinforcing effects of clonidine in baboons. Drug Alcohol Depend. 1999;53(3):207-214.

115. McCann DJ. Potential of buprenorphine/naltrexone in treating polydrug addiction and co-occurring psychiatric disorders. Clin Pharmacol Ther. 2008;83(4):627-630.

116. Mannelli P, Patkar AA, Peindl K, Gorelick DA, Wu LT, Gottheil E. Very low dose naltrexone addition in opioid detoxification: a randomized, controlled trial. Addict Biol. 2009;14(2):204-213.

117. Brower KJ. Insomnia, alcoholism and relapse. Sleep Med Rev 2003;7(6):523-539.

118. Kaplan GB, Heinrichs SC, Carey RJ. Treatment of addiction and anxiety using extinction approaches: neural mechanisms and their treatment implications. Pharmacol Biochem Behav. 2011;97(3):619-625.

119. Volkow ND, Wang GJ, Fowler JS, Tomasi D, Telang F, Baler R Addiction: decreased reward sensitivity and increased expectation sensitivity conspire to overwhelm the brain's control circuit. Bioessays. 2010;32(9):748-755.

120. Kosten TR, Morgan C, Kleber HD. Phase II clinical trials of buprenorphine: detoxification and induction onto naltrexone. NIDA Res Monogr. 1992;121:101-119.

121. Akhondzadeh S, Ahmadi-Abhari S, Assadi S, Shabestari O, Kashani A, Farzanehgan Z. Double-blind randomized controlled trial of baclofen vs. clonidine in the treatment of opiates withdrawal. J Clin Pharm Ther. 2000;25(5):347-353

122. Assadi SM, Radgoodarzi R, Ahmadi-Abhari SA. Baclofen for maintenance treatment of opioid dependence: a randomized double-blind placebo-controlled clinical trial [ISRCTN32121581]. BMC Psychiatry. 2003;3:16.

123. Gonzalez G, Sevarino K, Sofuoglu M, et al. Tiagabine increases cocainefree urines in cocaine-dependent methadone-treated patients: results of a randomized pilot study. Addiction. 2003;98(11):1625-1632.
124. Kheirabadi G, Ranjkesh M, Maracy M, Salehi M. Effect of add-on gabapentin on opioid withdrawal symptoms in opium-dependent patients. Addiction. 2008;103(9):1495-1499.

125. Martínez-Raga J, Sabater A, Perez-Galvez B, Castellano M, Cervera G. Add-on gabapentin in the treatment of opiate withdrawal. Prog Neuropsychopharmacol Biol Psychiatry. 2004;28(3):599-601.

126. Ji D, Gilpin NW, Richardson HN, Rivier CL, Koob GF. Effects of naltrexone, duloxetine, and a corticotropin-releasing factor type 1 receptor antagonist on binge-like alcohol drinking in rats. Behav Pharmacol. 2008;19(1):1-12.

127. Myers KM, Carlezon WA Jr. D-cycloserine facilitates extinction of naloxone-induced conditioned place aversion in morphine-dependent rats. Biol Psychiatry. 2009;67(1):85-87.

128. McCance-Katz EF, Sullivan LE, Nallani S. Drug interactions of clinical importance among the opioids, methadone and buprenorphine, and other frequently prescribed medications: a review. Am J Addict. 2010;19(1):4-16.

129. Saber-Tehrani AS, Bruce RD, Altice FL. Pharmacokinetic drug interactions and adverse consequences between psychotropic medications and pharmacotherapy for the treatment of opioid dependence. Am J Drug Alcohol Abuse. 2011;37(1):1-11.

130. Mann K, Hermann D. Individualised treatment in alcohol-dependent patients. Eur ArchPsychiatry Clin Neurosci. 2010;260(Suppl 2): S116-120.

131. Ooteman W, Naassila M, Koeter MW, et al. Predicting the effect of naltrexone and acamprosate in alcohol-dependent patients using genetic indicators. Addict Biol. 2009;14(3):328-337.

132. Olivares JM, Peuskens J, Pecenak J, Resseler S, Jacobs A, Akhras KS; e-STAR Study Group. Clinical and resource-use outcomes of risperidone long-acting injection in recent and long-term diagnosed schizophrenia patients: results from a multinational electronic registry. Curr Med Res Opin. 2009;25(9):2197-2206.

133. Kane JM, Eerdekens M, Lindenmayer JP, Keith SJ, Lesem M, Karcher K. Long-acting injectable risperidone: efficacy and safety of the first long-acting atypical antipsychotic. Am J Psychiatry. 2003;160(6):1125-1132.

134. Weiden P, Rapkin B, Zygmunt A, Mott T, Goldman D, Frances A. Postdischarge medication compliance of inpatients converted from an oral to a depot neuroleptic regimen. Psychiatr Serv. 1995;46(10):1049-1054
Substance Abuse and Rehabilitation

\section{Publish your work in this journal}

Substance Abuse and Rehabilitation is an international, peer-reviewed, open access journal publishing original research, case reports, editorials, reviews and commentaries on all areas of addiction and substance abuse and options for treatment and rehabilitation. The manuscript management system is completely online and includes a very quick and

\section{Dovepress}

fair peer-review system. Visit http://www.dovepress.com/testimonials. php to read real quotes from published authors. 